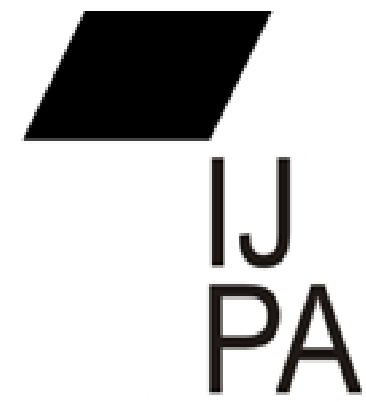

ISSN $2460=0369$

\title{
DINAMIKA PERENCANAAN ANGGARAN \\ PADA ANGGARAN PENDAPATAN \\ BELANJA DAERAH (APBD) BURU SELATAN
}

\author{
Marno Wance \\ Program Studi Ilmu Pemerintahan, \\ Fakultas Ekonomi dan Ilmu Sosial, \\ Universitas Pattimura, Indonesia \\ ipmummu@gmail.com
}

\begin{abstract}
This study aims to determine the dynamics of regional expenditure budget (APBD) formulation of the South Buru. The budget plan is a way to predict development planning for the next year including the income, the expenditure and the financing. Budget planning is a very important stage because the right budget will affect the regional development index. The method of this study is qualitative using interview and documentation as the instruments. The data are taken directly from the respondents or the objects of the study, while the supporting data are obtained through written documents namely the General Policy Budget - Temporary Priority Budget Platform (KUA-PPAS), Budget Policy Plan Regional Work Unit (RKA-SKPD), South Buru Regional Expenditure Budget (APBD), and documents taken from the fractions of the Regional Representative Council and agencies or institutions related to research. The problems analysed in this study use the concept of regional legislative processes, the concepts and stages of budget planning. The approach used is ROCCIPI model theory (Rule, Capacity, Communication, Interest, Ideology).
\end{abstract}

Keywords: budget dynamics; formulation, south buru regional expenditure budget. 
Abstrak. Penelitian ini bertujuan untuk mengetahui dinamika perumusan APBD Buru Selatan. Rencana anggaran merupakan cara untuk memperdiksi perencanaan pembangunan satu tahun ke depan yang mencakup pendapatan, pengeluaran serta pembiayaan. Perencanaan anggaran merupakan tahapan yang sangat penting karena anggaran yang tepat sasaran akan berpengaruh pada indeks pembangunan daerah. Metode yang digunakan dalam penelitian ini adalah kualitatif dengan menggunakan instrument wawancara serta dokumentasi. Pendekatan yang digunakan langsung dari responden atau objek yang diteliti, sedangkan sumber data adalah sumber data yang diperoleh melalui dokumen-dokumen tertulis yaitu Kebijakan Umum Anggaran-Platfom Prioritas Anggaran Sementara (KUAPPAS), Rencana Kebijakan Anggaran-Satuan Kerja Perangkat Daerah (RKA-SKPD), Anggaran Pendapatan Belanja Daerah (APBD) Buru Selatan, dokumen pandangan fraksi Dewan Perwakilan Rakyat Daerah mapun instansi atau lembaga yang berhubungan dengan penelitian. Analisis permasalahan pada penelitian ini menggunakan konsep proses legislasi daerah, konsep perencanaan anggaran serta konsep tahapan-tahapan anggaran. Pendekatan penelitian menggunakan teori model ROCCIPI (Rule, Capacity, Comunication, Interest, Ideologi).

Kata kunci: dinamika anggaran; perumusan, APBD Buru Selatan. 


\section{PENDAHULUAN}

\section{Pengertian Anggaran pendapatan Belanja Daerah (APBD)}

Menurut Freeman dalam Nordiawan, dkk (2003), Anggaran adalah sebuah proses yang dilakukan oleh organisasi publik untuk mengalokasikan sumber daya yang dimilikinya pada kebutuhan-kebutuhan yang tidak terbatas (the process of allocating resources to unlimitied demands). Senada dengan apa yang di sampaikan oleh Bastian (2002) bahwa Pengertian APBD “Anggaran Pendapatan dan Belanja Daerah merupakan pengejawantahan rencana kerja Pemerintah Daerah dalam bentuk satuan uang untuk kurun waktu satu tahun tahunan dan berorientasi pada tujuan kesejahteraan publik".

Sementara yang dikemukakan oleh Nordiawan, dkk (2007), “APBD merupakan rencana keuangan tahunan pemerintah daerah yang disetujui oleh DPRD dan ditetapkan dengan peraturan daerah". Selain itu, menurut Mardiasmo (2005), “Anggaran Pendapatan dan Belanja Daerah merupakan instrumen kebijakan yang utama bagi pemerintah daerah. Sebagai instrumen kebijakan, anggaran daerah menduduki posisi sentral dalam upaya pengembangan kapabilitas dan efektivitas. Anggaran daerah digunakan sebagai alat untuk menentukan besar pendapatan dan pengeluaran, membantu pengambilan keputusan dan perencanaan pembangunan, otorisasi pengeluaran di masa-masa yang akan datang, sumber pengembangan ukuran-ukuran standar untuk evaluasi kinerja, alat untuk memotivasi para pegawai, dan alat koordinasi bagi semua aktivitas dari berbagai unit kerja".

Menurut UU No. 33 tahun 2004, “Anggaran pendapatan dan belanja daerah yang selanjutnya disebut APBD adalah suatu rencana keuangan tahunan daerah yang ditetapkan berdasarkan peraturan daerah tentang APBD”. Pada Permendagri Nomor 11 Tahun 2006, "APBD merupakan dasar pengelolaan keuangan daerah dalam masa 1 (satu) tahun anggaran terhitung 1 Januari sampai 31 Desamber".

Semua Penerimaan dan Pengeluaran Daerah harus dicatat dan dikelola dalam APBD. Penerimaan dan pengeluaran daerah tersebut adalah dalam rangka pelaksanaan tugas-tugas desentralisasi. Sedangkan penerimaan dan pengeluaran yang berkaitan dengan pelaksanaan Dekonsentrasi atau Tugas Pembantuan tidak dicatat dalam APBD.

APBD merupakan dasar pengelolaan keuangan daerah dalam satu tahun anggaran. APBD merupakan rencana pelaksanaan semua Pendapatan Daerah dan semua Belanja dalam rangka pelaksanaan Desentralisasi dalam tahun anggaran tertentu. Pemungutan semua penerimaan Daerah bertujuan untuk memenuhi target yang ditetapkan dalam APBD. Demikian pula semua pengeluaran daerah dan ikatan yang membebani daerah dalam rangka pelaksanaan desentralisasi dilakukan sesuai jumlah dan sasaran yang ditetapkan dalam APBD. Karena APBD merupakan dasar pengelolaan keuangan daerah, maka APBD juga menjadi dasar bagi kegiatan pengendalian, pemeriksaan dan pengawasan keuangan daerah. 
Maka berdasarkan pada konsep Anggaran di atas oleh sebab itu Tahun anggaran APBD sama dengan tahun anggaran APBN yaitu mulai 1 Januari dan berakhir tanggal 31 Desember tahun yang bersangkutan. Sehingga pengelolaan, pengendalian, dan pengawasan keuangan daerah dapat dilaksanakan berdasarkan kerangka waktu tersebut.

\section{Tahapan-Tahapan Dalam Siklus Anggaran}

Menurut Mardiasmo (2002) tahapan-tahapan yang dilakukan dalam penyusunan anggaran sektor Publik adalah sebagai berikut:

Tahap Persiapan dan Penyusunan Anggaran. Pada tahap persiapan dan penyusunan anggatan dilakukan taksiran pengeluaran atas dasar taksiran pendapatan yang tersedia. Terkait dengan masalah tersebut, yang perlu diperhatikan adalah sebelum menyetujui taksiran pengeluaran, hendaknya terlebih dahulu dilakukan penaksiran pendapatan secara lebih akurat, selain itu harus disadari adanya masalah yang cukup berbahaya jika anggaran pendapatan diestimasi pada saat bersamaan dengan pembuatan keputusan tentang anggaran pengeluaran. Dalam persoalan estimasi, yang perlu mendapat perhatian adalah terdapatya faktor "Uncertainty" (tingkat ketidakpastian) yang cukup tinggi. Oleh sebab itu, manajer keuangan publik harus memahami betul dalam menentukan besarnya suatu mata anggaran. Besarnya suatu mata anggaran sangat tergantung pada teknik dan sistem anggaran yang digunakan.

Tahap Ratifikasi Anggaran. Tahap berikutnya adalah Budget Ratification. Tahap ini merupakan tahap yang melibatkan proses politik yang cukup rumit dan cukup berat. Pimpinan eksekutif (kepala daerah) dituntut tidak hanya memiliki "Managerial Skill" namun juga harus mempunyai "Political Skill," "Salesmanship," dan "Coalition Building" yang memadai. Integritas dan kesiapan mental yang tinggi dari eksekutif sangat penting dalam tahap ini. Hal tersebut penting karena dalam tahap ini pimpinan eksekutif harus mempunyai kemampuan untuk menjawab dan memberikan argumentasi yang rasional atas segala pertanyaanpertanyaan dan bantahan-bantahan dari pihak legislatif.

Tahap Pelaksanaan Anggaran (Budget Impleméntation). Setelah anggaran disetujui oleh legislaiif, tahap berikutnya adalah pelaksanaan anggaran. Dalam tahap ini, hal terpenting yang harus diperhatikan oleh manajer keuangan publik adalah dimilikinya sistem (informasi) akuntansi dan sistem pengendalian manajemen. Manajer keuangan publik dalam hal ini bertanggung jawab untuk menciptakan sistem akuntansi yang memadai dan handal untuk perencanaan dan pengendalian anggaran yang telah disepakati, dan bahkan dapat diandalkan untuk tahap penyusunan anggaran periode berikutnya. Sistem akuntansi yang digunakan hendaknya juga mendukung pengendalian anggaran.

Tahap Pelaporan dan Evaluasi Anggaran. Tahap terakhir dari siklus anggaran adalah pelaporan dan evaluasi anggaran. Tahap persiapan, ratifikasi, dan implementasi anggaran terkait dengan aspek operasional anggaran, sedangkan tahap pelaporan dan 
evaluasi terkait dengan aspek akuntabilitas. Apabila pada tahap implementasi telah didukung dengan sistem akuntansi dan system pengendalian manajemen yang baik, maka pada tahap pelaporan dan evaluasi anggaran biasanya tidak akan menemui banyak masalah.

\section{Proses pembuatan legislasi pada Pembahasan APBD}

Proses pembahasan legislasi tersebut menjadi tidak demokratis manakala pengakomodasian nilai-nilai dan kepentingan masyarakat yang beragam itu didominasi oleh pihak-pihak kuat dan dominan tertentu. Jika ini terjadi berarti dalam pengelolaan nilai-nilai dan kepentingan yang berbeda-beda itu pada ujungnya berakhir dengan penundukan nilai-nilai yang dihayati dan kepentingan golongan yang lemah oleh golongan yang kuat. Ini bermakna bahwa proses pembentukan hukum tidak demokratis, sebab Dworkin menegaskan bahwa dalam demokrasi itu "All Members of the Community, as Individuals, With Equal Concern and Respect". (Frank Michelman (2003).

Untuk mengkualifikasikan proses legislasi pada pembahasan APBD yang partisipatif, efektif dan akuntabilitas, maka indikator yang digunakan dalam kajian penelitian untuk sesuai dengan proses pembahasan Anggaran Pendapatan Belanja Daerah (APBD). Maka metode yang dipakai dalam menganalisis suatu kebijakan publik yaitu seperti Regulatory Impact Assessment (RIA) maupun model ROCCIPI (Rule, Opportunity, Capacity, Communication, Interest, Process, Ideology).

Menurut Takuji Kameyama (2003) dalam bukunya Manual Review Regulasi Indonesia yaitu Pada dasarnya Regulatory Impact Assessment (RIA) digunakan untuk menilai suatu regulasi dalam hal: 1) Relevansi antara kebutuhan masyarakat dan sasaran kebijakan. 2) kebutuhan terhadap intervensi pemerintah. 3) Efisiensi antara input dan output. 4) Efektivitas antara sasaran kebijakan dan hasil. 5) Keberlanjutan antara kebutuhan masyarakat dan hasil sebelum diterapkannya atau dirubahnya suatu regulasi. Sedangkan tujuan RIA adalah sebagai berikut ini: (a) Menilai efektivitas regulasi dalam: (1) Menyelesaikan masalah yang ada, dan (2) Mencapai sasaran (objective), yang mendasari penerbitan regulasi tersebut. (b) Memastikan bahwa perumus regulasi telah mempertimbangkan semua alternatif tindakan (options) yang tersedia. (c) Meneliti berbagai manfaat dan biaya (dampak) dari suatu regulasi, terutama manfaat dan biaya yang harus dihadapi para fihak yang terkena regulasi. (d) Memastikan bahwa dalam semua tahapan perumusan regulasi telah dilakukan koordinasi dan konsultasi yang memadai dengan para pihak yang terkait (stakeholders), dan (e) Menilai strategi implementasi regulasi, termasuk administrasi, sosialisasi, dan monitoring pelaksanaan kebijakan.

Sedangkan model ROCCIPI (Rule, Opportunity, Capacity, Communication, Interest, Process, Ideology). adalah untuk mengindentifikasi 7 (tujuh) faktor yang sering menimbulkan masalah berkaitan dengan berlakunya suatu hukum. Ketujuh faktor 
tersebut dapat dipilah menjadi dua katagori faktor penyebab, yaitu faktor subjektif dan faktor objektif. Faktor subjektif terdiri atas Interest dan Ideology. Sedangkan faktor objektif terdiri atas: Rule, Opportunity, Capacity, Communication, dan Process.

Faktor Interest (kepentingan) mengacu pada manfaat bagi pelaku peran. Kepentingan ini bisa terdiri atas kepentingan ekonomi, kepentingan politik, dan kepentingan sosial budaya.

Faktor ideologi secara umum diartikan sebagai kumpulan nilai yang dianut oleh suatu masyarakat untuk merasa, berpikir, dam bertindak. Termasuk di dalamnya antara lain sikap mental, pandangan tentang dunia, dan pemahaman keagamaan. Kadangkadang ideologi juga disamakan dengan budaya yang sangat luas cakupannya.

Faktor Rule (peraturan) adalah menyangkut pemahaman hubungan antara patuh atau tidak patuhnya seseorang terhadap suatu peraturan. Dalam hal ini harus dipertimbangkan bahwa seseorang itu tidak hanya berhadapan dengan satu peraturan, namun oleh banyak peraturan yang ada kemungkinan tidak jelas atau bisa ditafsirkan sesuka hati masing-masing orang.

Faktor Opportunity (kesempatan) menunjuk pada suatu kemungkinan sebuah peraturan secara tegas melarang perilaku tertentu, namun jika terbuka kesempatan untuk tidak mematuhinya maka orang dengan mudah melakukan perilaku bermasalah.

Faktor Capacity (kemampuan) adalah mempertimbangkan kondisi-kondisi yang berada dalam diri orang yang menjadi subjek peraturan. Faktor ini menjadi pertimbangan untuk menentukan bahwa sebuah peraturan tidak dapat memerintahkan seseorang untuk melakukan sesuatu yang dia tidak mampu.

Faktor Communication (komunikasi) ini menyangkut langkah-langkah yang memadai bagi para pihak yang berwenang untuk mengkomunikasikan peraturanperaturan yang ada kepada pihak yang dituju.

Sedangkan Process (proses) menyangkut kriteria dan prosedur apa saja yang menjadi pertimbangan para pelaku peran memutuskan untuk mematuhi atau tidak mematuhi hukum. (Ann Seidman, et. al: 2001).

Studi ilmiah melalui RIA maupun analisis ROCCIPI tersebut dituangkan dalam naskah akademik yang sistematikanya berbeda dengan sistematika peraturan perundangundangan. Tujuan pembuatan naskah akademik adalah untuk memperoleh pandangan yang komprehensif atas suatu rancangan peraturan perundang-undangan yang akan disusun.

\section{METODE PENELITIAN}

Jenis Penelitian ini menggunakan pendekatan penelitian Deskriptif kualitatif yaitu ada beberapa definisi mengenai pendekatan ini, Bogdan dan Taylor ( dalam Moeleong, 
2011,) menjelaskan bahwa metodologi kualitatif sebagai prosedur penelitian yang menghasilkan data deskriptif berupa kata-kata tertulis atau lisan dari orang-orang dan perilaku yang dapat di amati. di mana metode yang di gunakan menekankan pada proses penelusuran data/informasi hingga di rasakan telah cukup di gunakan untuk membuat suatu interpretasi.

Tipe penelitian deskriptif yaitu bertujuan untuk mendeskripsikan secara terperinci mengenai fenomena-fenomena sosial tertentu yang berkenaan dengan masalah dan untuk diteliti. Senada apa yang di kemukakan oleh Sugiyono (2011) yang menjelaskan bahwa metode kualitatif digunakan untuk mendapatkan data yang mendalam, suatu data yang mengandung makna. Metode yang digunakan dalam pemecahan permasalahan termasuk metode analisis. Metode-metode yang digunakan dalam penyelesaian penelitian dituliskan di bagian ini.

\section{HASIL DAN PEMBAHASAN \\ PenyusunanAPBD Buru Selatan}

Pedoman dan format dalam perumusan kebijakan umum anggaran telah ditetapkan oleh pemerintah, dalam hal ini Menteri dalam Negeri yang dituangkan pada Permendagri Nomor 13 Tahun 2006 tentang Pedoman Pengelolaan Keuangan Daerah. Berkaitan dengan hal tersebut, maka pedoman penyusunan rancangan APBD, bagian ketiga tentang kebijakan umum dan prioritas plafon anggaran sementara, Pasal 83 sampai dengan pasal 86 pada intinya memuat ketentuan dalam mekanisme penyusunan dan penetapan kebijakan umum APBD. Ketentuan ini memberikan penegasan terhadap landasan kebijakan umum APBD yang harus diawali dengan kegiatan penjaringan aspirasi masyarakat, baik oleh pemerintah daerah maupun DPRD serta mengacu pada rencana strategis daerah dan dokumen perencanaan lainnya yang telah ditetapkan serta berpedoman pada pokok-pokok kegiatan nasional yang berkaitan dengan bidang keuangan daerah oleh Menteri Dalam Negeri.

Hasil dan pembahasan berisi hasil-hasil temuan penelitian dan pembahasannya. Tuliskan temuan-temuan yang diperoleh dari hasil-hasil penelitian yang telah dilakukan dan harus ditunjang oleh data-data yang memadai. Hasil-hasil penelitian dan temuan harus bisa menjawab pertanyaan atau hipotesis penelitian di bagian pendahuluan.

Tabel Perbandingan PAD di KUA-PPAS dan RAPBD Buru Selatan 2015

\begin{tabular}{|c|c|c|c|}
\hline Rincian & $\begin{array}{l}\text { KUA/PPAS Awal } \\
\text { (Rp) }\end{array}$ & $\begin{array}{l}\text { KUA Penyesuain/ RAPBD } \\
(\mathrm{Rp})\end{array}$ & $\begin{array}{c}\text { Bertambah/ (Berkurang) } \\
\text { (Rp) }\end{array}$ \\
\hline \multicolumn{4}{|l|}{ Pendapatan } \\
\hline Pendapatan Asli Daerah & 7.779 .300 .000 & 8.349 .300 .000 & 570.000 .000 \\
\hline Restribusi & 520.800 .000 & 520.800 .000 & - \\
\hline $\begin{array}{l}\text { Hasil Pengelolaan Kekayaan Daerah Yang } \\
\text { Dipisahkan }\end{array}$ & 200.000 .000 & 200.000 .000 & - \\
\hline Jumlah & 15.558.600.000 & 16.698.600.000 & 1.140 .000 .000 \\
\hline
\end{tabular}

Sumber: KUA PPAS Buru Selatan 
Pada tabel di atas bisa dilihat bahwa terjadi peningkatan Pendapatan Asli Daerah (PAD) yang dianggarkan sebesar Rp.7.779.300.00,- mengalami perubahan pada KUAPPAS penyesuaian RAPBD sebesar Rp.8.349.300.000,- atau bertambah sebesar Rp.570.000.000,-. Pada rincian pengusulan pajak pada KUA-PPAS awal sebesar Rp.1.058.500.000,- mengalami perubahan pada KUA-PPAS penyesuaian sebesar Rp.1.128.500.000,-atau bertambah sebesar Rp.70.000.000,-. Di lain pihak pada rincian lain-lain pendapatan daerah yang sah yang diusulkan sebesar Rp.6.000.000.000,mengalami perubahan pada KUA-PPAS penyesuaian sebesar RP.6.500.000.000,- atau bertambah sebesar Rp.500.000.000,-. Maka dari jumlah secara keseluruhan Pendapatan Asli Daerah (PAD) yang diusulkan sebesar KUA-PPAS awal Rp.15.558.600.000,mengalami perubahan pada KUA-PPAS perubahan sebesar Rp.16.698.600.000,- atau mengalami selisih sebesar Rp.1.140.000.000,--

Fraksi Karya Pembangunan Sejahtera yang di sampikan langsung oleh Masrudin Solissa., S.E memberikan pandangan Politik sebagai berikut:

Sesuai dengan Pasal 171, Permendagri No 13 Tahun 2006, yang telah diubah dalam Permendagri No. 59 Tahun 2007, Ranperda APBD sebelum diserahkan Kepala Daerah kepada DPRD harus disosialisasikan kepada masyarakat. Fraksi KPS menilai, pemerintah Daerah Kabupaten Buru Selatan belum menjalankan amanat permendagri ini dengan sungguh-sungguh. Kedepan, Pemerintah Kabupaten Buru Selatan harus menjalankan amanat ini sebagai bagian dari prinsip keterbukaan informasi yang menjadi hak dari masyarakat.

Dalam pembahasan RAPBD Tahun Anggaran 2015 ini terdapat beberapa dokumen yang terlambat, dan tidak diserahkan Pemerintah Daerah kepada DPRD, Fraksi KPS menyayangkan sikap tersebut sebagai bentuk ketidak patuhan terhadap Amanat ketentuan, ini menjadi catatan serius terhadap Pemerintah Daerah sehingga kedepan pentahapan-pentahapan diperhatikan sungguh sesuai amanat ketentuan yang berlaku.

Fraksi KPS meminta Pemerintah Daerah Kabupaten Buru Selatan untuk melakukan perbaikan secara total dan komprehensif terkait dengan Selisih angka pada Pagu RKA dan RAPBD, sehingga tidak terjadi persoalan Hukum di tahun-tahun yang akan datang.(Sumber: Fraksi KPS Kabupaten Buru Selatan, 2015)

Kata Akhir Fraksi Partai Demokrat yang di sampaikan langsung oleh Ismail Loilatu., S.Hi memberikan beberapa pernyataan dan saran sebagai berikut:

Fraksi Partai Demokrat meminta dengan sangat kepada Pemerintah Daerah untuk membuat, menyusun dan mengkompilasi data potensi Pendapatan Daerah secara lengkap dan di update setiap tahunnya. Hal ini sangat penting dalam rangka mengukur efektifitas dan produktifitas Pemerintah Daerah dalam pengelolaan sumber-sumber Pendapatan Asli Daerah dimasa-masa yang akan datang.

Dalam mengelolah dan mengoptimalisasi potensi-potensi sumber Pendapatan Daerah mesti didukung dengan sumber daya manusia yang handal dan berdaya saing tinggi, untuk itu Fraksi Partai Demokrat mendorong Pemerintah Daerah untuk lebih selektif dalam hal penempatan tenaga pengelolah potensi-potensi Pendapatan Asli 
Daerah serta secara efektif dan efisien dapat mengoptimalkan setiap UPTD pendapatan pada setiap Kecamatan di Buru Selatan.

Terkait dengan Pajak Daerah, Fraksi Partai Demokrat memberikan apresiasi kepada pemerintah daerah yang telah berupaya meningkatkan realisasi target PAD dari sector pajak daerah meliputi pajak hotel, pajak restoran dan pajak bahan galian C. ini pertanda bahwa semakin banyak hotel, restoran dan pembangunan lainnya tumbuh pesat di negeri ini.semoga pencapaian pendapatan asli daerah dari sektor pajak daerah tersebut terus ditingkatkan ditahun-tahun yang akan datang. (Sumber: Fraksi Partai Demokrat Buru Selatan 2015).

Kata Akhir Fraksi PDI-Perjuangan yang langsung di sampaikan oleh Sami Latbual., S.H memberikan beberapa catatan penting sebagai berikut:

Terkait dengan kebijakan pengalokasian keuangan Daerah, Fraksi PDI-Perjuangan sangat menyayangkan, Pengalokasian anggaran dengan tidak memperhatikan Azas Pemerataan dan Kebutuhan pada tiap-tiap kecamatan.

Dalam perencanaan anggaran keuangan daerah, fraksi PDI-Perjuangan meminta kepada pemerintah daerah untuk lebih memperhatikan azas efisisensi dan efektifitas dengan orientasi lebih pada belanja publik dan peningkatan sumber daya manusia (SDM).

Mohon penjelasan terhadap standar pelayanan minimum (SPM) untuk setiap SKPD, serta sudah sejauh mana pemerintah Kabupaten Buru Selatan merumuskan efesiensi anggaran dan kualitas layanan publik. (Sumber: Fraksi PDI-Perjuangann, 2015).

Kata Akhir Fraksi Partai Amanat Nasional yang sampaikan langsung oleh Sedek Titawael,. S.H memberikan pandangan dan saran sebagai berikut:

Langkah-langkah yang harus dilakukan pemerintah Kabupaten Buru Selatan terkait dengan Dana Alokasi Umum (DAU) dari pemerintah pusat dalam rangka perimbangan belanja tidak langsung untuk gaji PNS disatu sisi belanja langsung yang sangat minim.

Apakah alokasi angggaran sudah cukup besar di Dinas Pendidikan sudah mencupi untuk memberikan kesejahteraan kepada Guru Honor.

Sebagai Pemerintah derah yang mempunyai kewenangah keuangan yang sangat besar, mestinya mempunyai semangat untuk meningkatkan PAD. (Sumber: Fraksi PAN Buru Selatan, 2015).

Akan tetapi, berdasarkan pada uraian pandangan dari Fraksi Partai Amanat Nasional (PAN), yang mempersoalkan langkah-langkah yang dilakukan pemerintah Kabupaten Buru Selatan dalam rangkan perimbangan belanja tidak langsung untuk gaji Pegawai Negeri Sipil (PNS) dalam mengurangi beban belanja langsung yang sangat minim. Maka akan diuraikan perbandingan belanja antara KUA-PPAS dan RAPBD pada anggaran 2015 yaitu sebagai berikut: 
Tabel Perbandingan Belanja di KUA-PPAS dan RAPBD Buru Selatan 2015

\begin{tabular}{|l|r|r|r|}
\hline \multicolumn{1}{|c|}{ Rincian } & KUA/PPAS Awal & KUA Penyesuaian/ RAPBD & Bertambah/ (berkurang) \\
\hline Belanja & & & $\mathbf{8 . 5 2 1 . 4 3 2 . 0 0 0}$ \\
\hline Belanja Tidak Langsung & $\mathbf{1 9 8 . 8 1 3 . 3 5 6 . 0 0 0}$ & $\mathbf{1 9 0 . 2 9 1 . 9 2 4 . 0 0 0}$ & 10.398 .882 .000 \\
\hline Belanja Pegawai & 158.021 .644 .000 & 147.622 .762 .000 & - \\
\hline Belanja Subsidi & 747.520 .000 & 747.520 .000 & 743.750 .000 \\
\hline Belanja Hibah & 6.450 .000 .000 & 7.193 .750 .000 & - \\
\hline Belanja Bantuan Sosial & 5.235 .832 .000 & 5.235 .832 .000 & 1.133 .700 .000 \\
\hline Belanja Bantuan Keuangan & 23.358 .360 .000 & 24.492 .060 .000 & - \\
\hline Belanja Tidak Terduga & 5.000 .000 .000 & 5.000 .000 .000 & 13.195 .009 .000 \\
\hline Belanja Langsung & 343.060 .213 .000 & 356.255 .222 .000 & $\mathbf{1 3 . 1 9 5 . 0 0 9 . 0 0 0}$ \\
\hline Belanja Langsung & $\mathbf{3 4 3 . 0 6 0 . 2 1 3 . 0 0 0}$ & $\mathbf{3 5 6 . 2 5 5 . 2 2 2 . 0 0 0}$ & \\
\hline
\end{tabular}

\section{Sumber: KUA PPAS Buru Selatan}

Berdasarkan pada tabel di atas bisa dilihat bahwa dari uraian belanja tidak langsung yang diusulkan pada KUA/PPAS awal mengalami peningkatan jumlah yaitu sebagai berikut: peningkatan terbesar pada belanja pegawai, Pada komponen belanja langsung dianggarkan sebesar Rp.356.255.222.000,- dari yang dianggarkan tahun lalu sebesar Rp.357.264.374.531,- berkurang sebesar 0,28\% atau menurun sebesar Rp.1.009.152.531,- komposisi belanja langsung dapat digambarkan sebagai berikut: belanja pegawai dianggarkan sebesar Rp.34.932.792.000,- dari anggaran tahun lalu sebesar Rp.31.347.763.000,- bertambah sebesar 11,44\% atau meningkatkan sebesar Rp.3.585.029.000,- belanja barang dan jasa dianggarkan Rp.116.593.813.000,- dari anggaran tahun lalu sebesar Rp.112.166.812.591,- atau mengalami peningkatan sebesar 3,95\% atau sama dengan Rp.4.427.000.409,- sedangkan belanja modal tahun lalu sebesar Rp.213.749.798.940,- yang berarti berkurang sebesar 4,22\% atau sama dengan Rp.9.021.181.940.

Kata Akhir Fraksi Perubahan yang langsung di sampaikan oleh Muhajir Bahta., S.IP memberikan pandangan politik sebagai berikut:

Pagu anggaran belum mampu mengatisipasi kemungkinan sutuasi sulit, bahkan kita belum mampu untuk mengfokuskan anggaran pada visi Pemerintah daerah. Mohon Penjelasan dari Wakil Bupati.

Apa langkah-langkah penghematan yang dilakukan pemerintah daerah dengan perencanaan yang matang sehingga tugas pokok dan fungsinya. Bagaimana dengan pemberian anggaran pada SKPD berdasarkan pada realisasi anggaran tahun sebelumnya.

Apakah Perencanaan anggaran yang di usulkan sudah melibatkan unsur-unsur terhadap bidang dan jenis program yang direncanakan, contohnya ahli ekonomi, ahli sosial-politik, ahli hukum, dan ahli budaya. (Sumber: Fraksi Perubahan Buru Selatan, 2015).

Tahap 3 (ketiga), Rapat paripurna selanjutnya di laksanakan Senin, 29 Desember 2014 pada pukul 11:3 WIT bertempat di ruangan sidang DPRD Kabupaten Buru Selatan tentang jawaban Bupati yang di wakil Bupati oleh Ayub Buce Saleky, S.H.,M.H, atas pandangan umum fraksi terhadap nota keuangan dan Raperda APBD Tahun 2015. Sidang paripurna dipimpin langsung oleh Pimpinan DPRD Buru Selatan yaitu La 
Hamidi (Wakil Ketua), Arkilaus Solissa (Ketua DPRD), Gerson E. Selsily, SE (Wakil Ketua) Yang Bertindak sebagai Sekretaris Rapat B. Wamaesa, S.Sos.,M.M (Pelaksana Tugas Sekretaris DPRD Buru Selatan). Jumlah anggota yang hadir 20 orang dari 20 jumlah keseluruhan, masing-masing Fraksi Partai Demokrasi Indonesia Perjuangan (4 Orang), Fraksi Demokrat (3 Orang), Fraksi Partai Amanat Nasional (3 Orang), Fraksi Partai Gerakan Indonesia Raya (3 Orang), Fraksi Karya Pembangunan Sejahtera (3 Orang), Fraksi Partai Perubahan (3 Orang). Dalam rapat tersebut dihadiri oleh Ayub Buce Saleky, S.H.,M.H, (wakil bupati), Para Muspida Buru Selatan, Sekretaris daerah Buru Selatan, Para Asisten, Kepala Badan, Kepala Kantor, Kepala Dinas, Kepala Bagian, dan Camat Se-Kabupaten Buru Selatan. Selanjutnya Pada Rabu 31 Desember 2014 pukul 14:32 WIT Wakil Bupati Ayub Buce Saleky, S.H.,M.H memberikan penjelasan umum tentang RAPBD Buru Selatan Tahun 2015 dihadapan Badan Anggaran DPRD, dengan kesimpulan rapat pembahasan Raperda Buru Selatan, akan dilajutkan dengan menghadirkan seluruh kepala SKPD Buru Selatan. (Sumber: Risalah

\section{Sidang DPRD Buru Selatan, 2015).}

Secara umum pembicaraan pada tingkat ke dua ini memuat pertanyaan yang terkandung dalam pandangan umum masing-masing fraksi. Kemudian di lanjutkan dengan jawaban bupati Buru Selatan yang memberikan tanggapan atas pertanyaanpertanyaan yang di sampaikan, sedangkan jawaban yang bersifat teknis akan dikemukakan masing-masing Kepala Satuan Kerja Perangkat Daerah (SKPD) dalam pembicaraan Tingkat III pada rapat komisi dan atau gabungan komisi yang dilakasnakan pada Rabu 26 November 2014. Pada forum tersebut menghadirkan seluruh SKPD untuk menyampaikan Rencana Kerja Anggaran (RKA) dihadapan Badan Anggaran (Banggar) DPRD dan Tim Panitia Anggaran Pemerintah Daerah (TAPD), Kesimpulan yang di ambil bahwa seluruh program yang di usulkan oleh Pemerintah Daerah di rasionalisasikan sesuai dengan kebutuhan yang menjadi prioritas masyarakat dan untuk mengehemat anggaran. (Risalah Sidang DPRD Buru Selatan, 2015).

Selanjutnya pembahasan RKA-SKPD yang belum tuntas di tingkat badan anggaran (Banggar) DPRD dilanjutkan pada 28/29 November 2015. Setelah melalui pembahasan yang sangat penuh dengan perdebatan dan pertentang tentang pririotas program kerja dan skala prioritas di tingkat badan anggaran (Banggar) DPRD maupun pada tingkat komisi, maka selanjutnya badan anggaran DPRD bersama TAPD pemerintah daerah memberikan pelaporan terhadap hasil rapat komisi dan dilanjutkan dengan penyelarasan anggaran baik jenis atau nama program maupun dari segi jumlah pembiayaannya. Dari hasil pembahasan laporan komisi tersebut pemerintah daerah melakukan penyesuaian dan perbaikan sesuai hasil penyerasian serta saran dan tanggapan dari pihak badan anggaran (Banggar) DPRD. (Risalah Sidang DPRD Buru Selatan, 2015).

Berdasarkan pada pandangan akhir Fraksi tersebut, maka rapat paripurna melahirkan keputusan DPRD Kabupaten Buru Selatan Tahun Anggaran 2015 dengan Nomor: 01/DPRD/II/2014 Tentang Persetujuan Penetapan Rancangan Peraturan Daerah Kabupaten Buru Selatan. Penetapan rancangan APBD Kabupaten Buru Selatan. Setelah 
tiap-tiap fraksi telah menyampaikan Pandangan akhir dan menyatakan menerima Rancangan Peraturan Daerah tentang APBD Kabupaten Buru Selatan tahun anggaran 2015 untuk ditetapkan menjadi peraturan daerah.

Pelaksanaan pembahasan dan penetapan rancangan APBD Kabupaten Buru Selatan tahun 2015 yang dibahasa secara bersama oleh pemerintah Kabupaten dengan DPRD pada dasarnya mengacu pada tata tertib Dewan Perwakilan Rakyat Daerah (DPRD) Kabupaten Buru Selatan. Pembahasan Rancangan peraturan daerah APBD Kabupaten Buru Selatan pada dasarnya dapat menghasilkan dua kemungkinan yaitu Pertama, persetujuan bersama dan penetapannya oleh DPRD dan Pemerintah Daerah melalui sidang paripurna DPRD. Kedua, apabila DPRD sampai batas waktu satu bulan sebelum anggaran dilaksanakan, tidak mengambil keputusan bersama, maka kepala daerah melaksanakan pengeluaran setinggi-tingginya sebesar angka APBD tahun anggaran sebelumnya untuk membiayai keperluan Tahun anggaran berjalan, yang disusun dalam rancangan peraturan kepala daerah tentang APBD.

\section{Proses Penyusunan RKA-SKPD}

Tahpan penyusunan Rencana Kerja Anggaran (RKA) SKPD di Kabupaten Buru Selatan tahun 2015 yang telah dilaksanakan proses penyusunan oleh masing-masing kepala SKPD, kemudian disampaikan kepada pejabat pengelolan keuangan daerah (PPKD) dan selanjutnya dibahas oleh Tim Anggaran Pemerintah Daerah (TPAD) yang di ketua langsung oleh Sekretariat Daerah (Sekda) Buru Selatan. Hal ini dilakukan untuk dapat menyesuaiakan antara dokumen RKA-SKPD dengan Kebijakan Umum Anggaran (RKA) APBD Tahun 2015, prioritas dan plafon anggaran dan dokumen perencanaan lainnya. Setelah dilakukan pembahasan dan terjadi ketidaksesuain maka kepala SKPD melakukan penyempurnaan. Maka pada Rancangan Peraturan Daerah (Raperda) tentang APBD Buru Selatan yang disusun oleh TPAD sebelum disampaikan kepada DPRD harus disosialisasikan oleh sekretaris daerah selaku kordinator pengelolaan keuangan pemerintah daerah kepada masyarakat, tujuannya untuk memberikan informasi mengenai hak dan kewajiban dalam pelaksanaan APBD tahun anggaran yang sudah direncanakan.

Pada dasarnya penyusunan, pembahasan dan pengesahan RKPD dilakukan oleh eksekutif yaitu Bappeda tanpa adanya peran dari legislatif, karena pada umumnya proses proses penyusunan, pembahasan dan pengesahan RKPD mengacu pada pada ketetapan Permendagri yang di keluarkan setiap tahun oleh pemerintah. Sehingga dalam pelaksanaan Musyawarah Perencanaan Pembangunan (Musrembang) merupakan salah satu tahapan penting dalam penyusunan RKPD. Musrembang RKPD adalah forum antar pemangku kepentingan guna membahas rancangan RKPD. Sesuai dengan tahapannya, Musrembang dapat di bagi menjadi Musrembang Desa sampai Musrembang Kabupaten untuk menyaring segala kehutuhan dasar masyarakat. Sedangkan pola interkasi Pemerintah daerah dan masyarakat selau mengalami keterlambatan baik dari pembahasan sampai pengesahan RKPD Kabupaten Buru Selatan. 
Tabel Pengesahan RKPD Kabupaten Buru Selatan Tahun 2015

\begin{tabular}{|c|c|c|c|}
\hline RKPD & Pengesahan & Batas & $\begin{array}{c}\text { Lama } \\
\text { Pengesahan }\end{array}$ \\
\hline 2010 & 16 November & $\begin{array}{c}\text { Akhir } \\
\text { Bulan Mei }\end{array}$ & 5 Bulan Lebih \\
\hline 2011 & $28 \mathrm{Juli}$ & $\begin{array}{c}\text { Akhir } \\
\text { Bulan Mei }\end{array}$ & 2 Bulan Lebih \\
\hline 2012 & 20 September & $\begin{array}{c}\text { Akhir } \\
\text { Bulan Mei }\end{array}$ & 4 Bulan Lebih \\
\hline 2013 & 30 Mei & $\begin{array}{c}\text { Akhir } \\
\text { Bulan Mei }\end{array}$ & Tepat Waktu \\
\hline 2014 & 29 November & $\begin{array}{c}\text { Akhir } \\
\text { Bulan Mei }\end{array}$ & 5 Bulan Lebih \\
\hline
\end{tabular}

Sumber: Bappeda Kabupaten Buru Selatan Tahun 2015

Berdasarkan pada uraian tabel di atas terjadi keterlambatan pada penetapan Rencana Kerja Pemerintah Daerah (RKPD) yang menjadi kendala yang sering dihadapi pada proses perencanaan dan penganggaran yaitu manakala aspirasi yang tumbuh dan berkembang dari masyarakat terbaikan begitu saja dan tidak terserap pada APBD Buru Selatan. Jika hal tesebut sering dilakukan maka pola pendekatan yang dilakukan melalui Musrembang Desa sebagai pendekatan pembangunan partisipatif hanya slogan yang manis dibicarakan namun pahit dalam pelaksanaannya. Maka penetapan program prioritas pada RKPD harus berorientasi pada pemenuhan hak-hak dasar masyarakat, asas pemerataan dan pencapaian keadilan yang berkesinambungan dan berkelanjutan. Disamping itu, proses penyusunan RKPD Kabupaten Buru Selatan harus mempunyai keterkaitan dengan pedoman RPJMD RPJPD dan RTRW Buru Selatan.

\section{Tahapan Penyusunan KUA-PPAS}

Proses penyusunan KUA-PPAS Kabupaten Buru Selatan Tahun 2015 pada pembahasan RAPBD, yang di atur oleh Permendagri Nomor 13 Tahun 2006 tentang pedoman pengelolaan keuangan daerah. Sehingga yang menjadi syarat untuk merumuskan KUA-PPAS dengan melakukan penjaringan aspirasi masyarakat yang menjadi acuannya yaitu dokumen perencanaan daerah, Rencana Kerja Pemerintah Daerah (RKPD) serta perencanaan nasional maupun kebijakan pemerintah pusat yang berlaku. Penjaringan Aspirasi yang dilakukan oleh DPRD Kabupaten Buru Selatan dilakukan dalam upaya untuk menampung segala kebutuhan-kebutuhan masyarakat di Daerah Pemilihan masing-masing.

Peraturan Menteri Dalam Negeri Nomor 13 Tahun 2006 jo Peraturan Menteri Dalam Negeri Nomor 59 Tahun 2007 tentang Pedoman Pengelolaan Keuangan Daerah, pasal 31 ayat 1,2, dan 3, menegaskan bahwa belanja penyelenggaraan urusan wajib diprioritaskan untuk melindungi dan meningkatkan kualitas kehidupan masyarakat dalam upaya memenuhi kewajiban daerah yang diwujudkan dalam bentuk peningkatan pelayanan dasar, pendidikan, kesehatan, fasilitas sosial dan fasilitas umum yang layak serta mengembangkan sistem jaminan sosial.

\section{Grafik Jumlah Anggaran KUA-PPAS Per Badan/ Kantor Kabupaten Buru Selatan Tahun 2015}




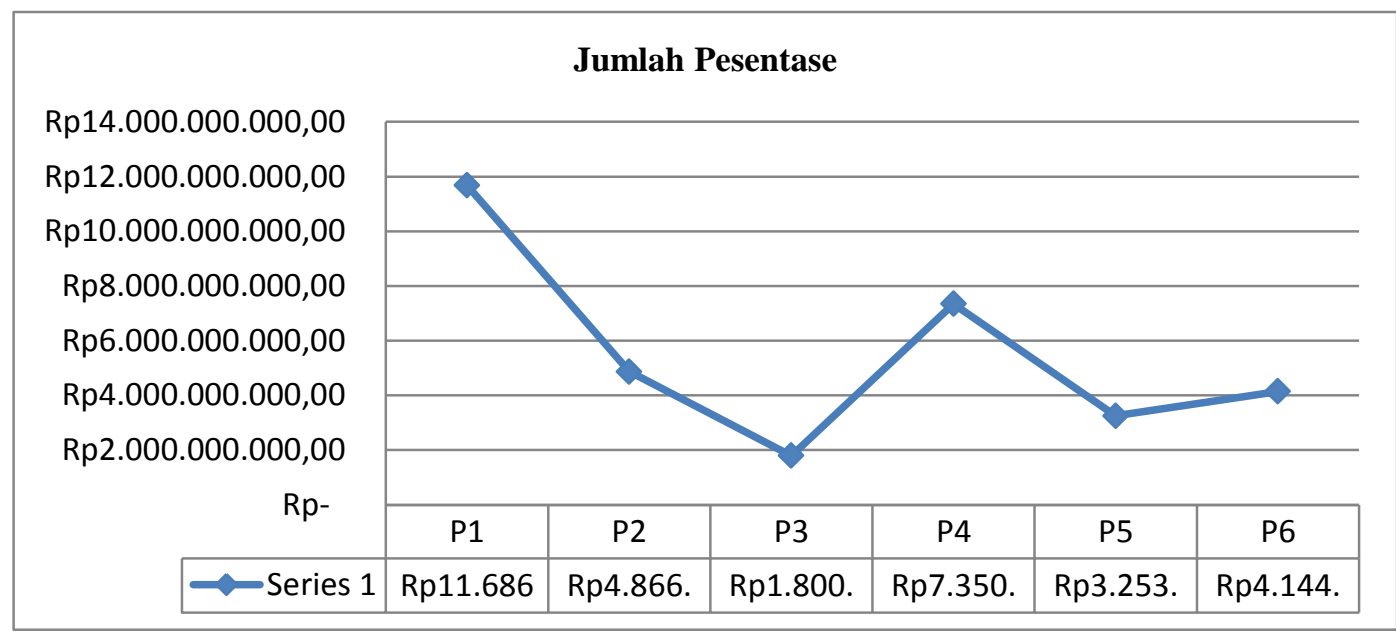

\section{Sumber: KUA-PPAS Kabupaten Buru Selatan, 2015}

Keterangan:

P1.= Bappeda dan Litbang: Rp.11.686.953.100

$P 2 .=$ Badan Lingkungan Hidup: Rp.4.866.600.000

P3. = Badan Penanaman Modal Daerah: Rp.1.800.000.000

P4. = Badan Kesatuan Bangsa dan politik dalam Negeri: Rp.7.350.000.000

P5. = Badan Ketahanan Pangan: Rp.3.253.069.000

P6. = Badan Pemberyaan Masyarakat dan Desa: Rp.4.144.922.000

Pada grafik di atas menunjukan bahwa persentase anggaran yang di ajukan berdasarkan badan/kantor di KUA-PPAS Kabupaten Buru Selatan Tahun 2015. Adapun persentase anggaran terbesar yaitu sebagai berikut: (1). Bappeda dan Litbang (Rp.11.686.953.100), (2). Badan Lingkungan Hidup (Rp.4.866.600.000),(3). Badan penanaman modal daerah (Rp.1.800.000.000), (4). Badan kesatuan bangsa dan politik dalam negeri (Rp.7.350.000.000), (5). Badan pemberdayaan masyarakat dan desa (Rp.4.144.922.000), (6). Badan ketahanan pangan (Rp.3.253.069.000).

\section{Rancangan Pembiayaan Pada KUA-PPAS Buru Selatan 2015}

Mengacu pada ketentuan Pasal 20 ayat (1) Peraturan Pemerintah Nomor 58 Tahun 2005 tentang Pengelolaan Keuangan Daerah, menyebutkan bahwa struktur APBD merupakan satu kesatuan yang terdiri atas pendapatan daerah, belanja daerah dan pembiayaan daerah. Pembiayaan daerah merupakan transaksi keuangan untuk menutup difisit atau memanfaatkan surplus anggaran. Apabila anggaran diperkirakan defisit, maka perlu dicari sumber-sumber pembiayaan untuk menutupi defisit tersebut dan sebaliknya, apabila anggaran diperkirakan surplus maka harus dimanfaatkan melalui pembiayaan.

Apabila terjadi defisit anggaran maka di gunakan pembiayan yaitu Pertama Penerimaan Pembiayaan adalah semua penerimaan daerah yang perlu/harus dibayar kembali. Penerimaan Pembiayaan Daerah meliputi Sisa Lebih Perhitungan Anggaran Sebelumnya (SILPA), penerimaan dana cadangan, hasil penjualan kekayaan daerah yang dipisahkan, penerimaan pinjaman daerah, penerimaan kembali pemberian 
pinjaman dan penerimaan piutang daerah. Penerimaan pembiayaan dalam APBD Kabupaten Buru Selatan Tahun Anggaran 2015 direncanakan hanya bersumber dari Sisa Lebih Perhitungan Anggaran Tahun Sebelumnya (SILPA).

Kedua, Pengeluaran Pembiayaan adalah semua pengeluaran daerah yang akan diterima kembali. Pengeluaraan pembiayaan daerah meliputi pembentukan dana cadangan, penyertaan modal (Investasi) Pemerintah daerah, pembayaran pokok hutang yang jatuh tempo, dan pemberian pinjaman daerah. Dalam tahun 2015, pengeluaran pembiayaan diperuntukkan bagi penyertaan modal (Investasi) Pemerintah Daerah pada Bank Pembangunan Daerah Maluku, dan bantuan dana bergulir kepada Koperasi Unit Desa (KUD).

\section{Grafik}

\section{Rancangan Belanja Daerah Pada KUA-PPAS di Kabupaten Buru Selatan 2015}

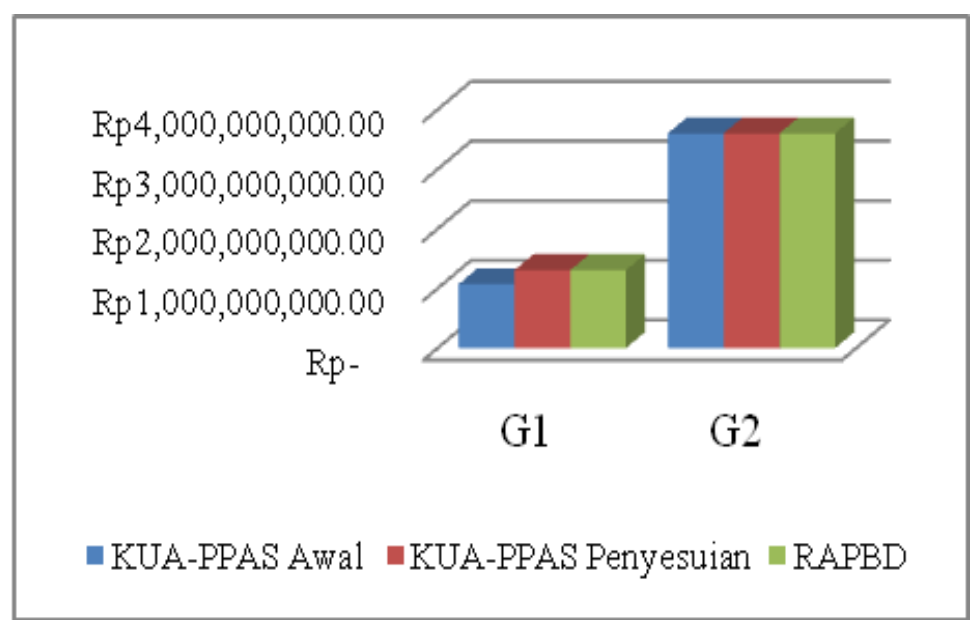

Sumber: KUA-PPAS Buru Selatan, 2015

Keterangan:

G1.= Penerimaan pembiayaan

G2. = Pengeluaran pembiayaan

Berdasarkan pada grafik di atas menunjukan bahwa rancangan belanja daerah pada KUA-PPAS Buru Selatan Tahun 2015, hanya satu uraian penerimaan yang terjadi selisih yaitu pada penerimaan pembiayaan, KUA-PPAS awal (Rp.1.070.000.000), pengesahan RAPBD (Rp.1.304.878.000), atau selisih KUA-PPAS (Rp.234.878.000). sedangkan pengeluaraan pembiayaan mengalami konsistensi penyusunan dari KUAPPAS awal sampai pengesahan RAPBD. Sehingga KUA-PPAS Kabupaten Buru Selatan tahun 2015 disusun berdasarkan Rencana Kerja Pemerintah Daerah (RKPD) dan kebijakan umum anggaran pendapatan dan belanja daerah, disusun sebagai salah satu dokumen perencaan pembangunan tahunan yang akan digunakan oleh pemerintah daerah sebagai acuan dalam rangka penyusunan rancangan anggaran pendapatan dan belanja daerah (RAPBD). 
Maka untuk menganalisis pola relasi eksekutif dan legislatif pada pembahasan APBD Kabupaten Buru Selatan Tahun 2015 maka Tahapan Kebijakan Umum Anggaran (KUA) dan Prioritas dan Platfon Anggaran Sementara (PPAS) akan ditemukan bentuk-bentuk pententangan yang selalu berdampak negatif dan selalu bertolak belakang dengan dengan pola-pola hubungan antara eksekutif maupun legislatif secara kelembagaan. Bentuk-bentuk pertentangan yang muncul dalam penyelenggaraan pemerintah adalah pola pertentanagn politik yang melibatkan berbagai macam kelompok kepentingan untuk menjadikan prioritas anggaran sebagai objek kepentingan kelempok tertentu.

\section{PENUTUP}

Adapun kesimpulan dari hasil penelitian ini adalah sebagai berikut:

Pihak Pemerintah Kabupaten Buru Selatan (eksekutif) pada pembahasan KUA dan PPAS pada umumnya bersifat koersif di mana masing-masing SKPD memiliki kewenangan di fungsi penganggaran.Sementara, pola relasi perilaku ofensif lebih ditonjolkan ketika telah berdialog secara bersama dengan institusi DPRD (Legislatif) untuk membahas mulai pada penyusunan rancangan maupun perumusan APBD Kabupaten Buru Selatan.

Perencanaan anggaran oleh Pemerintah Kabupaten (Eksekutif) dan DPRD (Legislatif) lebih dominan pada saat rapat pembahasan RAPBD pada masing-masing komisi yang membidangi beberapa SKPD terkait, maka posisi DPRD secara umum menunjukan perilaku yang dominani pembahasan anggaran. Pola relasi DPRD cenderung melakukan negosiasi, lobby kepentingan proyek pada Sub program yang terdapat pada tiap SKPD. Maka di setiap proses pembahasan anggaran yang melibatkan DPRD selalu diwarnai oleh negosiasi anggaran publik.

\section{DAFTAR PUSTAKA}

\section{Pustaka berupa judul buku:}

Bastian, Indra. 2002. Akuntansi Sektor Publik Di Indonesia, BPFE: Yogyakarta

Mardiasmo. 2004. Otonomi dan Manajemen Keuangan Daerah, Andi: Yogyakarta

Nordiawan, Iswahyudi dan Maulidah. 2007. Akuntansi Pemerintahan. Salemba Empat: Jakarta.

Michelman, Frank 2003 'Democracy and Positive Liberty'. In Campbell, Tom and Stone Adrienne (Ed.) Law and Democracy. Dartmouth Publishing Company Ashgate Publishing Limited, Burlington.

Moleong, J.L, 2007, Metodologi Penelitian Kualitatif (Edisi Revisi), Bandung: PT Remaja Rosda Karya. 
Wance, M., \& Djae, R. M. (2019). Dominasi Kuasa pada Pemilihan Kepala Desa Serentak di Kabupaten Halmahera Selatan Provinsi Maluku Utara. ARISTO, 7(2), 204-227. http://journal.umpo.ac.id/index.php/aristo/article/view/1607

Watungadha, marianus. "pelaksanaan hak inisiatif dewan perwakilan rakyat daerah dalam pembentukan peraturan daerah di kabupaten ngada pada tahun 20092014." (2015): 1-26.

Wance, M. (2016). Pola Relasi Eksekutif Dan Legislatif Pada Penyusunan Legislasi Daerah (Studi Di Pembahasan APBD Kabupaten Buru Selatan 2015). http://journal.umy.ac.id/index.php/GPP/article/viewFile/2643/2606

Wance, M. (2017). POLITIK ANGGARAN EKSEKUTIF DAN LEGISLATIF PADA PEMBAHASAN APBD KABUPATEN BURU SELATAN 2015. JOURNAL OF GOVERNMENT (Kajian Manajemen Pemerintahan dan Otonomi Daerah), 2(2), 178-204. http://journal.uta45jakarta.ac.id/index.php/gov/article/view/623

Subarsono. 2005. Analisis Kebijakan Publik. Yogyakarta: Pustaka Peajar.

\section{Pustaka yang berupa Prosiding Seminar:}

Wance, M., \& Suranto, S. (2017). Pola Relasi Eksekutif Dan Legislatif Pada Penyusunan Legislasi Daerah. Journal of Governance and Public Policy, 4(1), 108-141. http://repository.umy.ac.id/handle/123456789/8940 